\title{
RNA-DEPENDENT RNA POLYMERASE (RDRP) INHIBITOR DRUGS AGAINST SARS-COV-2: A MOLECULAR DOCKING STUDY
}

\author{
SARS-COV-2'YE KARŞI RNA-BAĞIMLI RNA POLIMERAZ (RDRP) INHİBITTÖR ILAÇLARI: \\ BIR MOLEKÜLER DOCKING ÇALIŞMASI
}

\begin{abstract}
Sarah GADO $^{1} \mathbb{D}^{\mathbb{D}}$, Zeynep ATES ALAGOZ ${ }^{1 *}$
${ }^{1}$ Ankara University, Faculty of Pharmacy, Department of Pharmaceutical Chemistry, 06560, Ankara, Turkey
\end{abstract}

\begin{abstract}
Objective: SARS-CoV-2 associated viral pandemic was first reported in Wuhan, China, in December 2019. Due to the rapid increase in its pathogenicity, SARS-CoV-2 was declared a global pandemic by WHO on March 11, 2020. For that reason, determining the most attractive viral protein targets became a must. One of the most important target proteins is SARS-COV-2 RNA-dependent RNA polymerase (RdRp) on which COVID-19 depends in its replication process. This study aimed to examine the possible interactions between RdRp and the most promising RdRp nucleoside inhibitors especially Purine nucleoside analogs, to detect the most important residues that commonly interact with RdRp's inhibitors and to investigate whether if there any mutations have been observed so far in these residues or not.

Material and Method: Molecular docking studies were carried out using AutoDock Vina between SARSCoV-2 RdRp and drugs approved against different viral RdRps (Galidesivir, Remdesivir, Ribavirin, Sofosbuvir, and Favipiravir) as well as physiological nucleotides (ATP and GTP). Based on the obtained results, a detailed surface-interaction analysis was also performed using Pymol and Discovery Studio Visualizer software for the models that exhibited the most suitable location and configuration in space.

Result and Discussion: All the tested molecules were able to bind to SARS-CoV-2 RdRp successfully. Also, they all commonly interact with 9 different amino acids (Arg553, Arg555, Asp618, Asp623, Ser682, Asn691, Ser759, Asp760, and Asp761), and 3 different Template-primer RNA nucleotides (U10, A11, and U20) causing inhibition of viral RdRp via non obligate RNA chain termination.

Keywords: COVID-19, molecular docking, RdRp, nucleotide analogs

ÖZ
\end{abstract}

\footnotetext{
* Corresponding Author/Sorumlu Yazar: Zeynep Ates Alagoz e-posta / e-mail: zates@ pharmacy.ankara.edu.tr, Tel./ Phone: +903122033078
} 


\begin{abstract}
Amaç: SARS-CoV-2 ile ilişkili viral pandemisi ilk olarak Aralık 2019'da Çin'in Wuhan kentinde bildirilmişstir. enfeksiyon gücünün yüksek olması nedeniyle, Dünya Sağllk Örgütü (DSÖ) 11 Mart 2020 tarihinde SARS-CoV-2'yi küresel pandemi olarak ilan etmiştir. Bu nedenle en önemli viral protein hedeflerinin belirlenmesi bir zorunluluk haline geldi. En önemli hedef proteinlerden biri ise, SARS-COV-2'nin replikasyon sürecinin bağll olduğu RNA'ya bağıml RNA polimerazdır (RdRp). Bu çalışmada RdRp ile RdRp nükleozit inhibitörleri, özellikle de Purin nükleozid analogları arasındaki olası etkileşimlerin incelenmesi, RdRp inhibitörleri ile yaygın olarak etkileşime giren en önemli kalıntıların saptanması ve bu kalıntılarda şimdiye kadar herhangi bir mutasyon gözlemlenip gözlemlenmediği araştırılması amaçlanmış̧tır.

Gereç ve Yöntem: SARS-CoV-2 RdRp'ye karşl fizyolojik nükleotidler (ATP ve GTP) ve farklı viral RdRpler'e karşı onaylanmış ilaçlar (Galidesivir, Remdesivir, Ribavirin, Sofosbuvir ve Favipiravir) olmak üzere toplam 7 bileşik test edilmişstir. RdRp ile bu 7 bileşik arasında AutoDock Vina yardımıyla moleküler docking çalışmaları gerçekleştirilmiş olup moleküler docking çalışmalarından elde edilen sonuçlara ve uzaydaki konfigürasyonlarına göre en uygun olan modelleri için de detayll yüzey etkileşim analizi Pymol ve Discovery Studio Visualizer software yardımıyla yapilmıştır.

Sonuç ve Tartışma: Test edilen tüm moleküller, SARS-CoV-2 RdRp'ye başarıyla bağlanabilmişstir. Ayrıca hepsi 9 farkl amino asit ile (Arg553, Arg555, Asp618, Asp623, Ser682, Asn691, Ser759, Asp760 ve Asp761) ayn zamanda 3 farkl Template-primer RNA nükleotidi (U10, A11 ve U20) ile etkileşime girmiş ve zorunlu olmayan RNA zinciri sonlandırmast yoluyla viral RdRp'nin inhibisyonuna neden olmuşlardır.

Anahtar Kelimeler: COVID-19, moleküler docking, RdRp, nükleotid analoglarl
\end{abstract}

\title{
INTRODUCTION
}

Viral infectious diseases continue to be a serious problem for human health. The global SARSCoV-2 associated viral pneumonia pandemic was first reported in Wuhan, China, in December 2019 [1]. Later then, SARS-CoV-2 was declared as a global pandemic by WHO on March 11, 2020, due to the rapid increase in its pathogenicity and rate of transmission. According to the WHO (COVID-19) Dashboard, as of 24 September 2021, a total of 230,418,451 confirmed cases of COVID-19 have been reported worldwide, including 4,724,876 deaths (https://covid19.who.int). This massive loss of population worldwide due to the SARS-CoV-2 pandemic has raised the urgent call for antiviral drugs for treatment/prevention against COVID-19. This study includes information about the biochemical structure of COVID-19 and its most important proteins that represent strategic targets to reveal the best treatment possibilities for coronavirus. As we aimed to examine in detail the biochemical structures of RNA-dependent RNA polymerase (RdRp), one of the most important proteins that COVID-19 depends on in its replication process, and its physiological nucleotide (ATP and GTP) as well as the most promising RdRp inhibitors such as Galidesivir, Remdesivir, Ribavirin, Sofosbuvir, and Favipiravir. Also, molecular docking studies and detailed surface interaction analysis were carried out between RdRp and these approved drugs, in the hope of making a little academic contribution to our heavy fight against COVID-19.

The new novel coronavirus belongs to the beta genus of coronavirus, which is non-segmented, enveloped, positive-sense, and single-stranded RNA viruses commonly found in mammals [2, 3]. SARS- CoV-2, as a positive-sense, single-stranded RNA virus, is capable of synthesizing a full-length negative-sense RNA strand that serves as a template for further production of Positive genomic RNA (gRNA) and subgenomic RNAs (sgRNAs) [4]. RNA viruses' hardship appears in their evolutionary 
capacity, exhibiting high mutation rates and frequent recombination [5]. The mechanisms of host shifting have been closely studied in emerging zoonotic viruses such as influenza virus, Hepatitis $\mathrm{C}$ virus, Ebola virus, (SARS-CoVs) [6]. SARS-CoV-2 has a unique survival strategy to balance viral replication with viral spread. In addition, COVID-19 exhibited an immunomodulatory profile that overstimulated the innate immune response and over suppressed the adaptive immune response [7]. In the disease caused by SARS-CoV-2, appears a clinical profile ranging from asymptomatic to severe respiratory failure, and the main symptoms of infection are cold, fever, pneumonia, cough, bronchiolitis with occasional diarrhea [8].

The SARS-CoV-2 genome is nearly $30 \mathrm{~kb}$ and encodes 29 proteins at least, including 4 structural proteins, 16 nonstructural proteins (NSPs), and 9 accessory proteins. On cell entry, the genomic RNA of SARS-CoV-2 is translated from two open reading frames ORF1a and ORF1b, to produce two overlapping polyproteins, pp1a and pp1ab, respectively. pp1ab is then cleaved into 16 NSPs by the viral proteases NSP3 and NSP5 [4]. While ORFs at the 3' end encode four structural proteins and nine putative accessory factors [9]. Structural proteins are involved in the assembly of the virion and the pathogenesis of infection. Structural proteins are classified as follows: Envelope protein (E), Nucleocapsid protein $(\mathrm{N})$, Membrane proteins (M), and Spike glycoprotein (S) [10]. S-glycoprotein of SARS-CoV-2 initiates infection by binding to the host cell Angiotensin-converting enzyme 2 (ACE2) receptor to initiate viral entry as S-glycoprotein undergoes proteolytic cleavages by host proteases (such as Trypsin and Furin) [11]. Knowing the structural and functional properties of the SARS-CoV-2 main proteins will help the development of viral-specific drug treatments and vaccines.

Molecules targeted by specific antiviral agents must be required for the viral life cycle or immune clearance. Such molecules can be divided into two categories: viral molecules and host molecules necessary for the completion of virus replication [12]. COVID-19 Spike structural protein, as well as multiple nonstructural proteins that also function as viral enzymes such as RdRP (nsp12), 3CL protease (nsp5), papain-like protease (nsp3), and helicase (nsp13), play essential roles for viral entry into the host cell and intracellular replication. They are also considered important targets for antiviral development due to the absence of closely related host cell counterparts [9]. A key component, RNA-dependent RNA polymerase (RdRp), also known as nsp12, catalyzes viral RNA synthesis and thus plays a crucial role in the replication and transcription cycle of the COVID-19 virus [13].

\section{Biochemical Structure of RNA-dependent RNA Polymerase (RDRP)}

Nsp12 is the catalytic subunit and core component of CoVs RdRp. Nsp12 forms a complex with two cofactor proteins (nsp7 and nsp8) and participates in the RNA template-dependent synthesis of viral RNA in the presence of divalent metal ions. The binding of nsp12 to nsp 7 and nsp 8 enhances the binding processability of nsp12 to RNA template [14]. NSP12 has three domains, the RdRp domain (367-920 aa), the NiRAN domain (4-28 aa and 69-249 aa), and the interface domain (250-365 aa). The RdRp 
domain consists of three subdomains: the (Finger) subdomain (366-581 and 621-679 aa), the (Palm) subdomain (582-620 and 680-815 aa), and the (Thumb) subdomain (816-920 aa) [4] (Fig.1). An additional N-terminal $\beta$-Hairpin (residues Asp29 to Lys50) generated by a prominent CYRO-EM map is inserted into the groove compressed by the NiRAN domain and the Palm subdomain in the RdRp domain [13]. The nsp7-nsp8 pair shows a conserved structure similar to the SARS-CoV nsp7-nsp8 pair [15]. Unless that, The orientation of the N-terminal helix of the individual nsp8 monomer attached to Nsp12 is shifted in comparison with that of the nsp7-nsp8 pair [13] (Fig. 1).

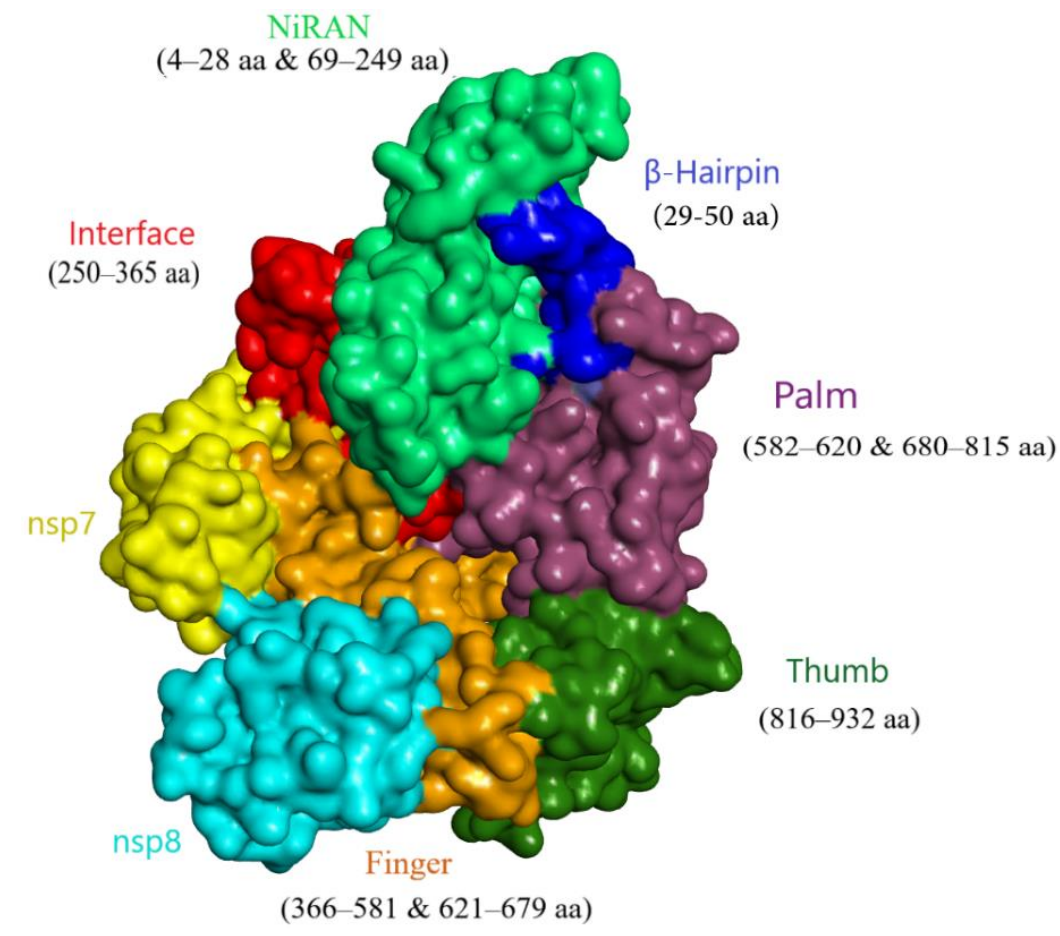

Figure 1. Structure of Nsp12 (RdRp)-Nsp7-Nsp8 complex of COVID-19

The cryo-electron microscopy structure of SARS-CoV-2 RdRp (PDB ID: 6M71) consisting of the Nsp12-nsp7-nsp8 complex is shown. Here, nsp7, nsp8-1 nsp8-2, Fingers domain, Thumb domain, Palm domain, NiRAN domain, $\beta$-Hairpin, and interface domain are shown in yellow, light blue, orange, dark green, purple, light green, blue, and red colors, respectively. The structure demonstration was made with the Discovery Studio Visualizer software.

With the accumulation of increasing knowledge about the disease and treatment experience, diagnostic and treatment programs for COVID-19 are constantly updated. Notably, antiviral drugs, antibiotics, antiprotozoal drugs, fusion inhibitors, immunomodulatory and anti-inflammatory drugs are the drug categories commonly used [16]. An efficient approach to boost drug discovery is to examine whether currently approved antiviral drugs are effective in treating COVID-19 or not [17]. The antiviral chemotherapeutic treatment concept usually relies on targeting specific viral enzymes or attacking a weak point of viral replication, such as targeting different RdRps [18]. Especially when the RdRp 
inhibition process is not expected to cause target-related side effects. The availability of antiviral drugs specific to SARS-CoV-2 will be an urgent need in parallel with preventive vaccines.

\section{RNA-dependent RNA Polymerase (RdRp) Inhibitors}

One of the major strategies used in the RdRp enzyme inhibition process is the use of nucleotide triphosphate analogs which prevent the binding of natural substrates through steric exclusion [19]. Nucleoside inhibitors are generally metabolized inside cells to their corresponding triphosphate forms then bound to the active site of viral polymerases, for that reason, they are called Active site ligands [20]. There are two known classes of RdRp inhibitors: nucleoside analog inhibitors (NIs) and nonnucleoside analog inhibitors (NNIs). As this study aimed to focus on nucleoside inhibitors, NIs terminate the RNA synthesis step, which is essential for RNA replication, through their incorporation by RdRp, which prevents incoming nucleotides from being added to the RNA chain [21]. Because of this mechanism, NIs are mostly called chain termination inhibitors (Fig. 2).
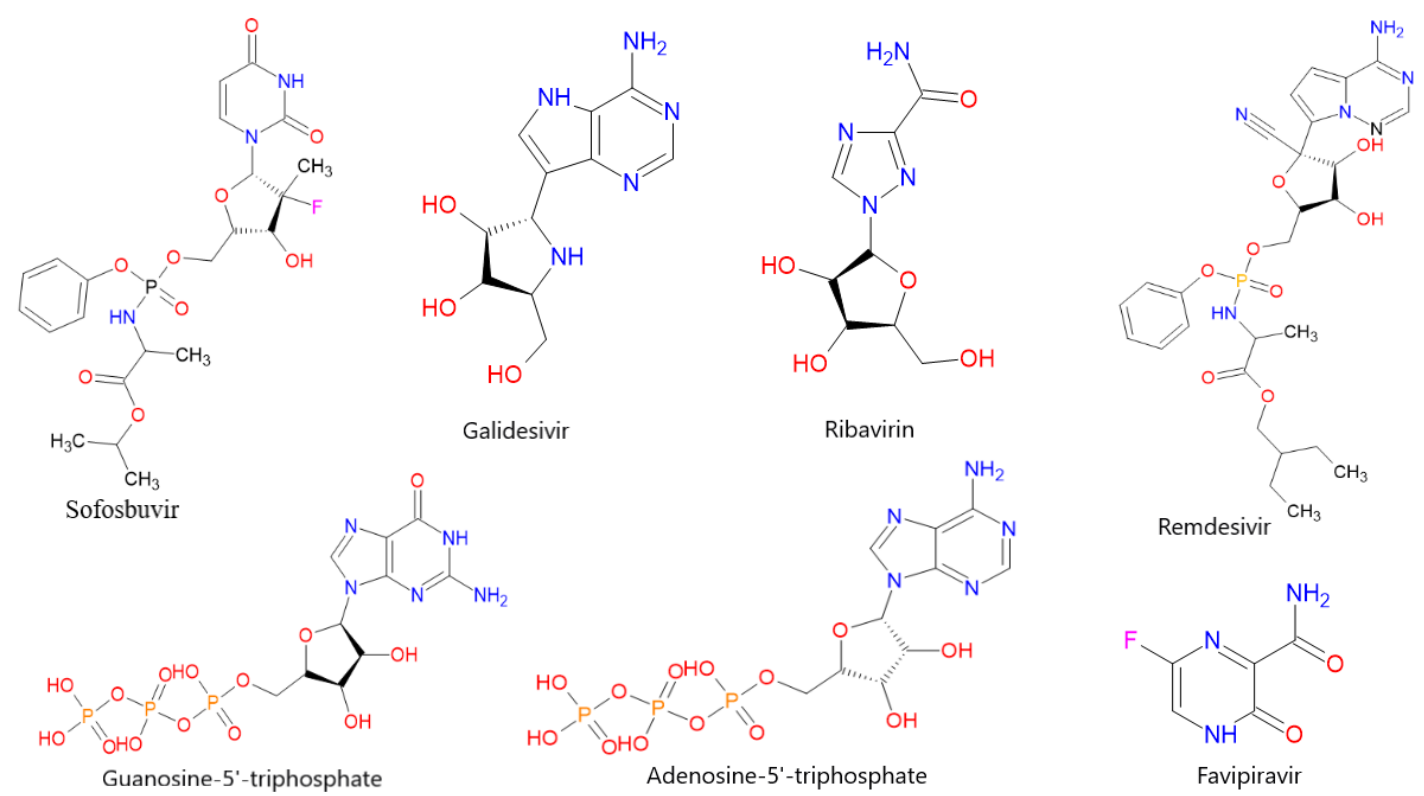

Figure 2. The chemical structure of the physiological nucleotides (ATP and GTP) and the five purine nucleoside inhibitor drugs approved against different viral RdRps (Galidesivir, Remdesivir, Ribavirin, Sofosbuvir, and Favipiravir)

\section{MATERIAL AND METHOD}

To examine the dissolved crystal structure of SARS-CoV-2 RNA-dependent RNA polymerase (RdRp) and to use it in docking trials, an electron microscopy crystallographic structure of SARS-CoV2 nsp12 in complex with its cofactors (nsp7 and nsp8) and Remdesivir-TP as an inhibitor (PDB ID: 7BV2 $2.5 \AA$ ), was retrieved from Protein Data Bank (www.rcsb.org) and was selected to be the target 
protein in the docking processes. And for protein preparation Chimera and Autodock 4 programs were used.

Before testing the ligands against SARS-CoV-2 RdRp, the structures of the ligands were ensured to be in the active (triphosphate) form. Pymol software was used to build up the Remdesivir triphosphate, Galidesivir triphosphate, and Sofosbuvir triphosphate molecules from their monophosphate molecules retrieved from Pubchem. However, other ligands were directly retrieved from the PubChem web server.

For performing molecular docking, AutoDock Vina software was used in all of the docking trials, in which the SARS-CoV-2 RdRp was treated as a rigid protein target, and the ligands were flexible. After molecular docking processes, the obtained models were analyzed using Protein-Ligand Interaction Profiler (PLIP) web server, Pymol, and Discovery Studio Visualizer.

\section{RESULT AND DISCUSSION}

To examine the dissolved crystal structure of SARS-CoV-2 RNA-dependent RNA polymerase (RdRp), an electron microscopy crystallographic structure of SARS-CoV-2 nsp12 in complex with its cofactors (nsp7 and nsp8), and Remdesivir-TP as an inhibitor (PDB ID: 7BV2 2.5 $)$ ) was retrieved from Protein Data Bank and was selected to be the target protein in all docking processes. This protein consists of A chain (represents nsp12), B chain (represents nsp8), C chain (represents nsp7), T chain, and P chain (represent Template - Primer RNA), $2 \mathrm{Zn}$ ions and $2 \mathrm{Mg}$ ions. To get the target protein prepared for the docking process, Chimera software was used to replace any incomplete side chains using the Dunbrack 2010 Rotamer Library. Then Autodock4 Tools software was used to delete water molecules, add polar hydrogen, and calculate Kollman charges (16.001). After the protein preparation process, the validity of the target protein (1011 residues) was mediated by the Ramachandran plot (100\% of the residues in the allowed regions, $92.7 \%$ in the most favored region, and \%6.7 of the residues in additional allowed regions).

Before testing the ligands against SARS-CoV-2 RdRp, the structures of the ligands were ensured to be in the active (triphosphate) form. Pymol software was used to build up the Remdesivir triphosphate, Galidesivir triphosphate, and Sofosbuvir triphosphate molecules from their monophosphate molecules retrieved from Pubchem. However, other ligands were directly retrieved from the PubChem web server.

After the preparation of Ligands and target Protein, a literature search was carried out to identify key residues known to interact with Remdesivir triphosphate to determine the active site for the correct positioning of the Grid box. In addition, the original ligand (Remdesivir-TP) in the crystal structure of the target protein was used as a leader ligand for determining the active site. Then, AutoDock 4 Tools program was used for generating a Grid box of $(30 \AA \times 30 \AA \times 30 \AA)$ positioned in $(97.791,95.583$, 102.373) (Fig. 3).

For performing molecular docking, AutoDock Vina software was used in all of the docking trials 
in which the SARS-CoV-2 RdRp was treated as a rigid protein target and the ligands were flexible. 7 Compounds were tested against SARS-CoV-2 RdRp. Namely, the physiological nucleotides (ATP and GTP), and five purine nucleoside inhibitor drugs approved against different viral RdRps (Galidesivir, Remdesivir, Ribavirin, Sofosbuvir, and Favipiravir).

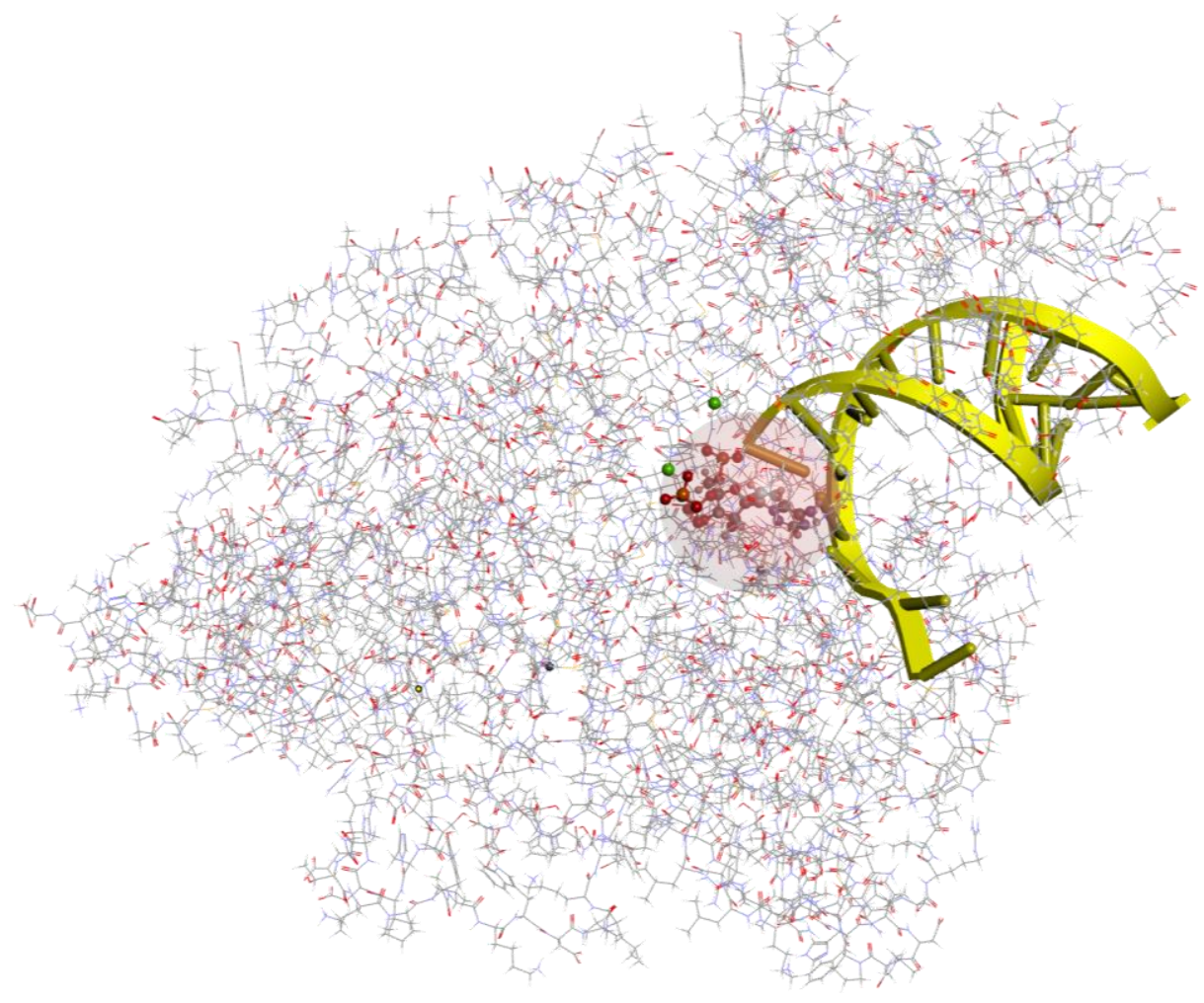

Figure 3. Cryo-electron microscopy structure of RdRp of SARS-CoV-2 with Remdesivir-TP

A cryo-electron microscopy structure of SARS-CoV-2 RdRp (PDB ID: 7BV2) composed of the triphosphate form (RTP) of Remdesivir, the catalytic $\mathrm{Mg}^{2+}$ ion, and the nsp12-nsp7-nsp8 complex bound to Template-primer RNA is shown. Here, Template-primary RNA is shown as a yellow ladder model while nsp12, nsp7, and nps8 are shown as lines. The triphosphate form (RTP) of Remdesivir is shown as a stick model and the surface by an atom is shown in light red to clearly illustrate the binding site used in our docking trials. The structure demonstration was made by Discovery Studio Visualizer software.

According to molecular docking results, the docking scores of the 7 compounds were found to be between -8.3 and $-7.7 \mathrm{Kcal} / \mathrm{mol}$. As the physiological compounds (ATP and GTP) exhibited binding energies of -7.8 to -7.4 and -7.7 to -7.3 respectively, while the five approved drugs Galidesivir, Remdesivir, Ribavirin, Sofosbuvir, and Favipiravir bound to SARS-CoV-2 RdRp with binding energies of -8.0 to -7.5 for Galidesivir-TP, -8.2 to -7.5 for Remdesivir-TP, -8.3 to -7.9 for Ribavirin-TP, -7.8 to 7.3 for sofosbuvir-TP, and -8.0 to -7.5 for Favipiravir (Fig. 4).

According to the results obtained from molecular docking trials, nucleotide analogs such as Galidesivir, Remdesivir, Ribavirin, Sofosbuvir, and Favipiravir were found to be able to bind to nsp12 associated with template-primer RNA causing inhibition of viral RdRp via non obligate RNA chain 
termination. Also, the binding energy values against RdRp for these drugs are better than the native nucleotides. In other words, these drugs have been found to have a higher binding affinity for RdRp compared to ATP and GTP.

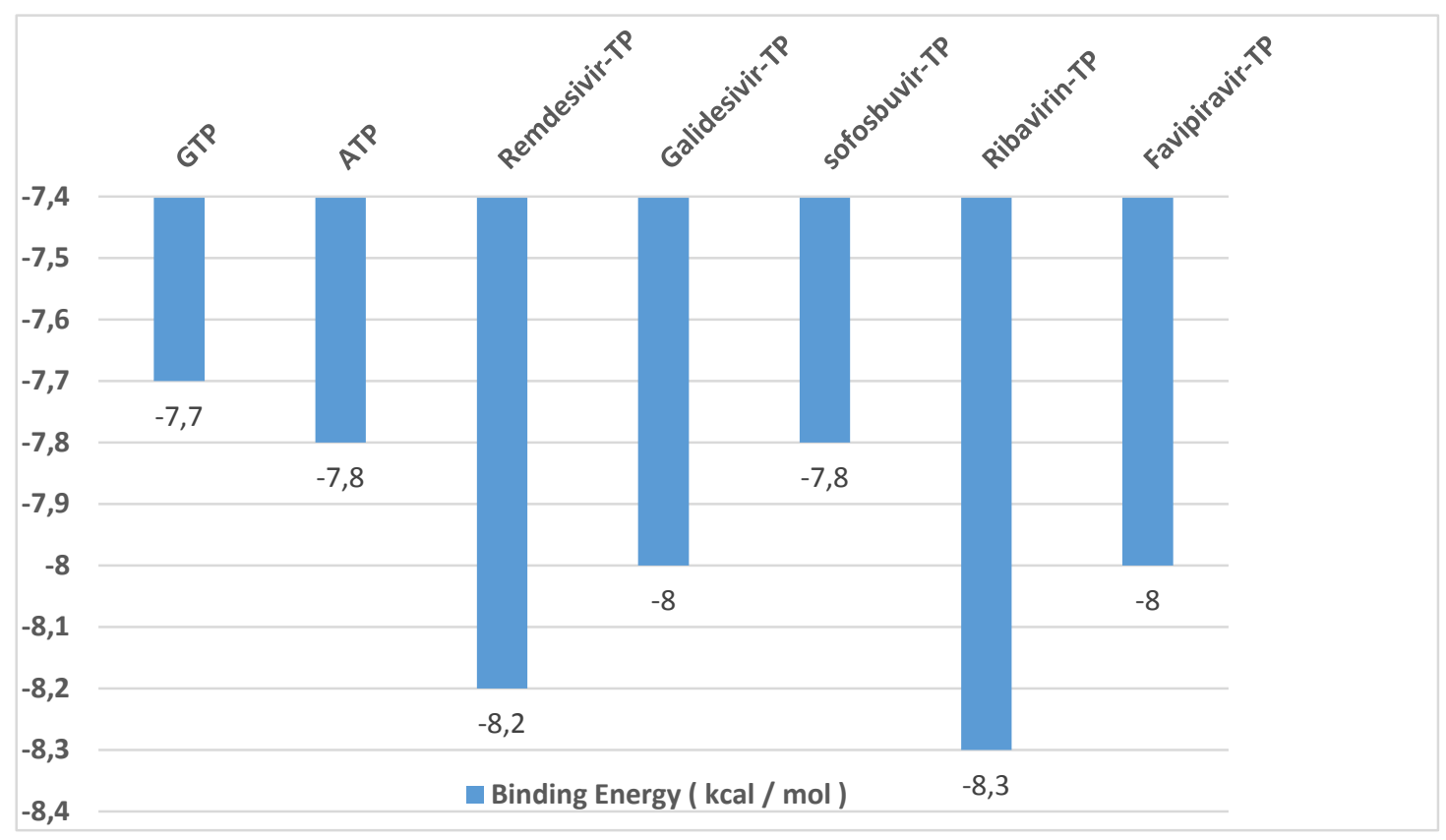

Figure 4. Docking scores of the physiological nucleotides (ATP and GTP) and five purine nucleoside inhibitor drugs approved against different viral RdRps (Galidesivir, Remdesivir, Ribavirin, Sofosbuvir, and Favipiravir) against SARS-CoV-2 RdRp

The models with the highest docking score in all the five drugs are located in the same position as the original Remdesivir-TP in the crystal structure of the target protein. This increases the reliability and accuracy of our molecular docking studies results (Fig. 5).

These approved drugs are thought to cause inhibition by mimicking the nucleoside substrate recognized by viral RNA polymerase. RdRp inhibition is also a superior approach because once these substrate mimetics bind, they are unable to induce virus "repair" and thus permanently block replication [22].

To investigate and discuss more possible interactions, models with the highest docking scores and best positions and configurations obtained from docking results were selected based on recent findings reported in articles and the results of similar studies. At the same time, the positions and configurations of the models produced from the docking trials were compared to the position and configuration of the original ligand (RemdesivirTP) in the crystal structure of the target protein and it was found that these models were the most suitable for studying surface-interaction analysis. According to the previous steps, the Complexes formed between selected models and RdRp were examined with the help of PLIP web- 
server, Pymol, and Discovery Studio Visualizer software.

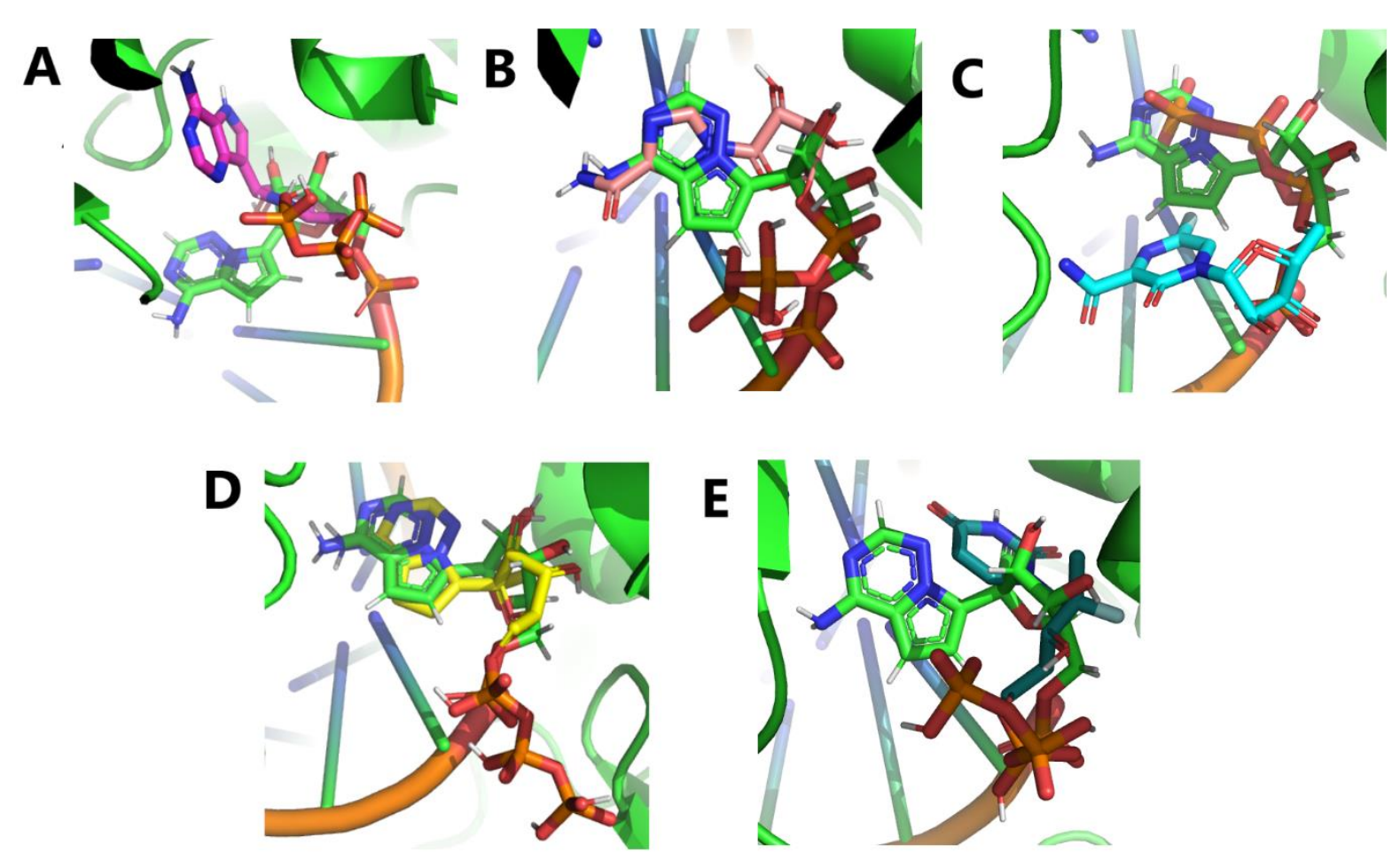

Figure 5. Comparison between the positions of the models produced from docking trials with the position of the original ligand

Here, The original ligand (RemdesivirTP) in the crystal structure of the target protein is shown in green, while;

A: Galidesivir-TP model $(-8.0 \mathrm{kcal} / \mathrm{mol})$ is shown in Pink

B: Ribavirin-TP model $(-8.3 \mathrm{kcal} / \mathrm{mol})$ is shown in Light orange.

C: Favipiravir-TP model $(-8.0 \mathrm{kcal} / \mathrm{mol})$ is shown in Cyan.

D: Remdesivir-TP model $(-8.2 \mathrm{kcal} / \mathrm{mol})$ is shown in Yellow.

E: Sofosbuvir-TP model $(-7.8 \mathrm{kcal} / \mathrm{mol})$ is shown in Dark Green.

According to the findings reported in different studies conducted on Remdesivir, Remdesivir in its monophosphate form (RMP), forms a covalent bond at the +1 position (via base-stacking interactions) with the $3^{\prime}$ end of the RNA primer chain, while interacting with the uridine base from the Template strand (via two hydrogen bonds). RMP also interacts with the side chains of Lys545 and Arg555 [14,23]. Interacting residues between Nsp12 and Remdesivir were obtained from the cryo-EM construct of SARS-CoV-2 RdRp. A total of 56 residues from Nsp12 were found to interact with Remdesivir. Specifically, certain nsp12 residues such as Ala558, Gly559, Ser682, Gly683, Asp684, Ser759, Asp760, Asp761, Cys813, and Ser814 interacted with Remdesivir and template-primer RNA and are required to maintain the catalytic activity of RdRp [23]. Moreover, the catalytic metal ions in SARS-CoV-2 nsp12 are coordinated by ternary aspartate, Asp618, Asp760, and Asp761, and the substrate p-phosphate is stabilized by Arg555. Asp623, Ser682, and Asn691 residues are observed to play a role in 2-OH 
recognition of the incoming nucleotide [24].

Some of these findings match our findings of the surface-interaction analysis of all the models, that they commonly interact with Arg555, Asp618, Asp623, Ser682, Asn691, Ser759, Asp760, and Asp761 residues (Fig. 6-7). A ligand-protein interaction diagram revealed that important residues of nsp12 are located within the $6 \AA$ distance of Remdesivir; showed metal coordination with $\mathrm{Mg}^{2+}$, hydrogen bonds of RNA with Asn691 and U10, and a pi-pi-Stacking interaction of Template-primer RNA with U20 [23]. These findings also match some of our findings of the surface-interaction analysis made within the $5 \AA$ distance of all the models, and it was found that they commonly interact with $\mathbf{U 1 0}$, A11, and U20 of Template-primer RNA (Fig. 6-7).

\section{Interactions}
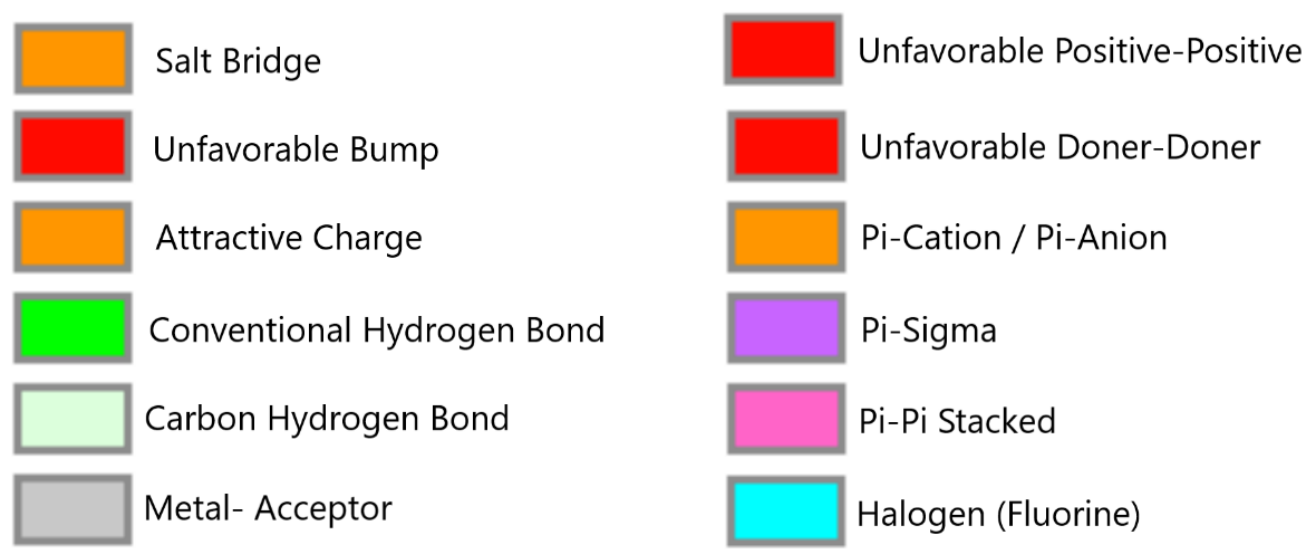

Figure 6. The types of intermolecular interactions are as labeled for all 2D ligand-protein interaction diagrams

To investigate the binding mode of the complexes formed between selected models and RdRp in detail, PLIP web-server and Pymol software were utilized for further 3D investigations.

- The interactions between the selected Favipiravir-TP model and RdRp are as follows:

11 H-bonds were formed with Arg555, Ser682 (2), Asn691, Ser759, Asp760 residues, primer U20 (4), and Template U10. In addition, the Favipiravir-TP model formed 2 salt bridges with Arg555 (2) and $1 \pi$-cation interaction with Arg555 (Fig. 8 A)

- While the interactions between the selected Ribavirin-TP model and RdRp are as follows:

14 H-bonds were formed with Arg555 (2), Asp623 (2), Ser682, Asn691, Ser759 (2), Asp760 residues, primer U20 (2), Template U10 (2), and A11. In addition, the Ribavirin-TP model formed 2 salt bridges with Arg555 (2), $1 \pi$-cation interaction with Arg555, and $\pi$-Stacking interaction with A11 (Fig. $8 \mathrm{~B})$ 


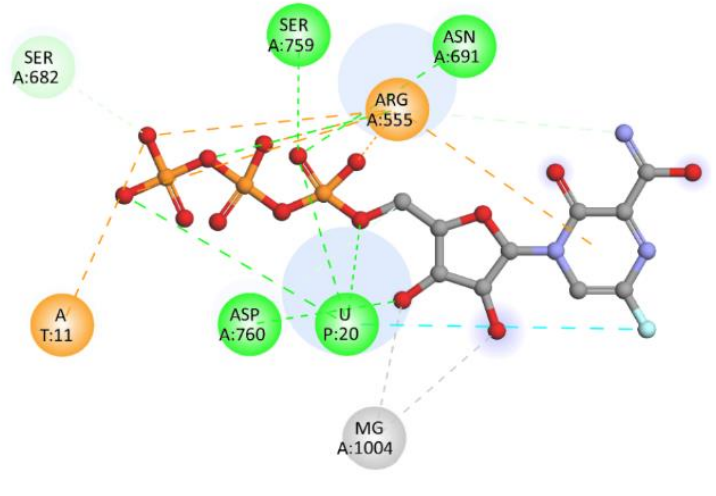

Favipiravir Triphosphate model

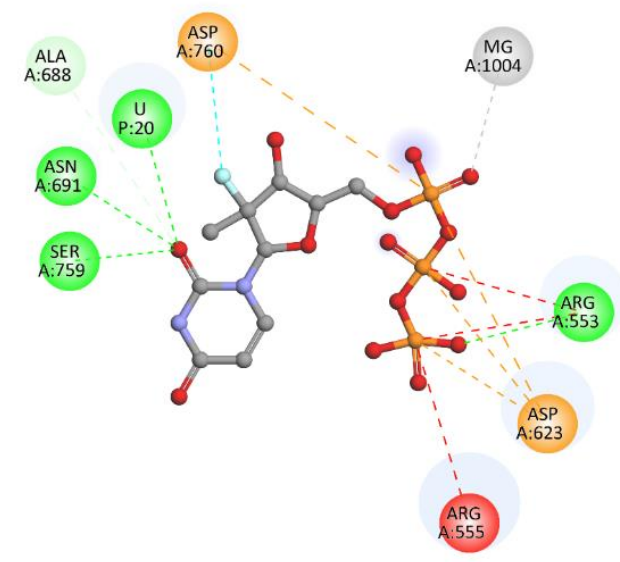

Sofosbuvir Triphosphate model

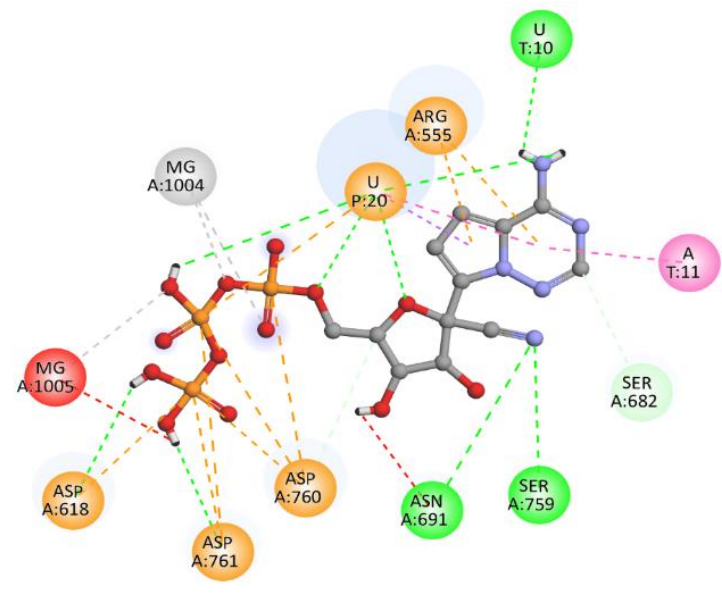

Remdesivir Triphosphate model

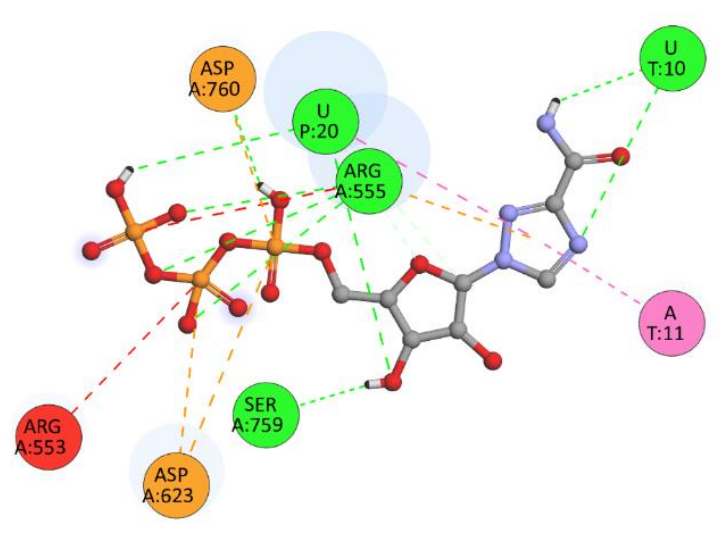

Ribavirin Triphosphate model

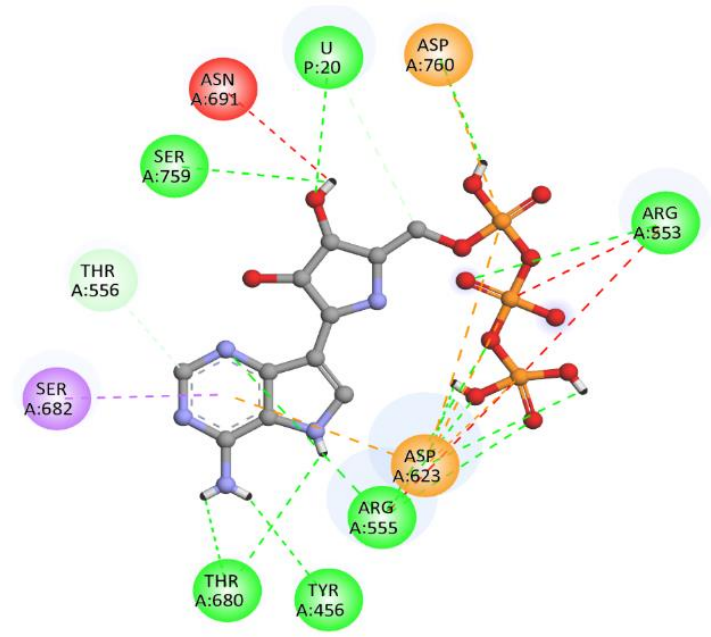

Galidesivir Triphosphate model

Figure 7. Ligand-protein interaction (2D) diagrams of all tested purine nucleoside inhibitor models, diagrams were made within a $5 \AA$ distance of the nsp12-nsp7-nsp8 complex bound to template-primer RNA and the types of interactions were shown as labeled in figure 6, diagrams were made with Discovery Studio Visualizer software 
A

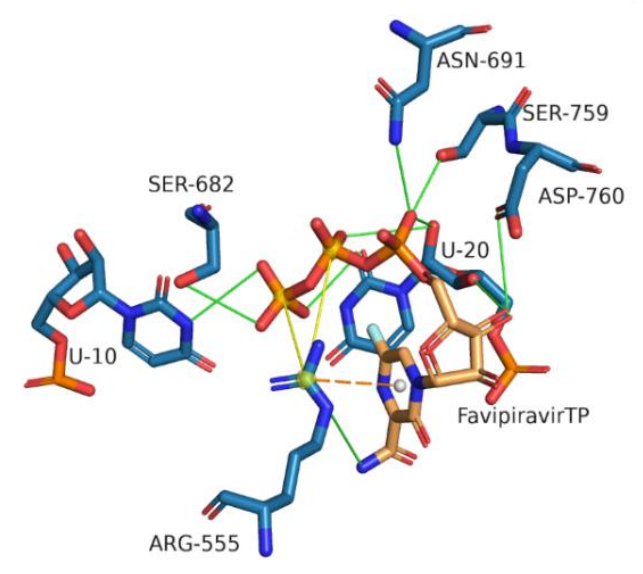

B

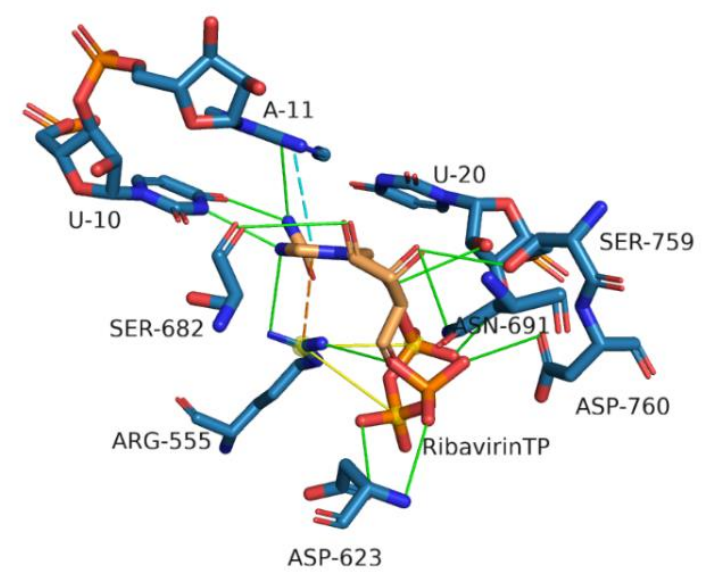

Figure 8. Favipiravir-TP and Ribavirin-TP ligand-protein interactions

Visualization of SARS-CoV-2 RdRp nsp12 active site and docked position with compound Favipiravir-TP and Ribavirin-TP models. Here, solid green lines depict the H-bonds, Solid Yellow lines depict salt-bridges, dashed orange lines depict $\pi$-cation interactions while dashed light blue lines depict $\pi$-Stacking interactions.

- The interactions between the selected Remdesivir-TP model and RdRp are as follows:

10 H-bonds were formed with Arg555, Asn691, Ser759, Asp760 residues, primer U20 (5), and Template U10. In addition, the Remdesivir-TP model formed $2 \pi$-cation interactions with Arg555 (2) and $1 \pi$-stacking interaction with primer U20 (Fig. 9 A)

- While the interactions between the selected Sofosbuvir-TP model and RdRp are as follows:

6 H-bonds were formed with Arg555, Asp623, Arg624, Asn691, Ser759 residue, and primer U20. In addition, the Sofosbuvir-TP model formed 3 salt bridges with Arg555 (2), Arg553, and hydrophobic interaction with Asp623 (Fig. 9 B).

- The interactions between the selected Galidesivir-TP model and RdRp are as follows:

12 H-bonds were formed with Tyr456, Arg555, Asp623 (3), Thr680 (2), Asn691, Ser759(2), Asp760 residues, and primer U20. In addition, the Galidesivir-TP model formed 4 salt bridges with Arg555 (2), Arg553 (2), and hydrophobic interaction with Asp623 (Fig. 10).

In conclusion, according to the results obtained from molecular docking studies and the results of detailed surface-interaction analysis for different models -which are the most suitable according to their positions and configurations- were found that they commonly interact with 9 different amino acids (Arg553, Arg555, Asp618, Asp623, Ser682, Asn691, Ser759, Asp760, and Asp761), and 3 different Template-primer RNA nucleotides (U10, A11, and U20) causing inhibition of viral RdRp via non obligate RNA chain termination.

In particular, it was found that all the models have formed different types of interactions with important residues such as Arg555, Ser759, Asp760 and with important nucleotides such as forming $\pi$ stacking interaction with primer $\mathbf{U} 20$ of Template-primer RNA. In addition, it can be said that Arg555, in particular, plays a very important role in the inhibition process held by nucleotide analogs because all 
the models have been found to form at least 2 or 3 different types of interaction with Arg555.

A

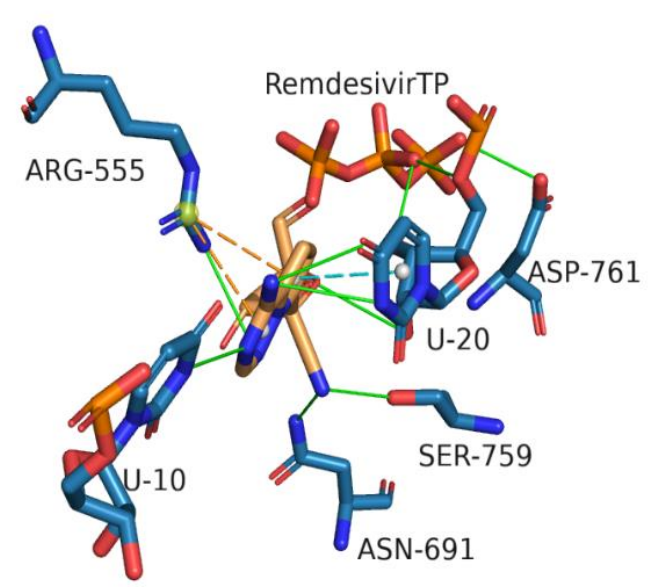

B

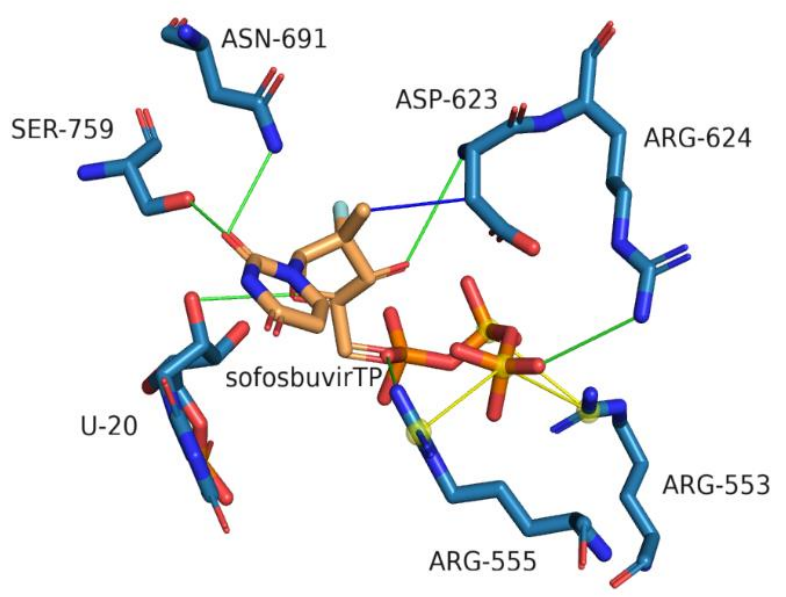

Figure 9. Remdesivir-TP and Sofosbuvir-TP ligand-protein interactions.

Visualization of SARS-CoV-2 RdRp nsp12 active site and docked position with compound Remdesivir-TP and Sofosbuvir-TP models. Here, solid green lines depict the H-bonds, Solid Yellow lines depict salt-bridges, solid blue lines depict hydrophobic interaction, dashed orange lines depict $\pi$-cation interactions, while dashed light blue lines depict $\pi$-Stacking interactions.

A

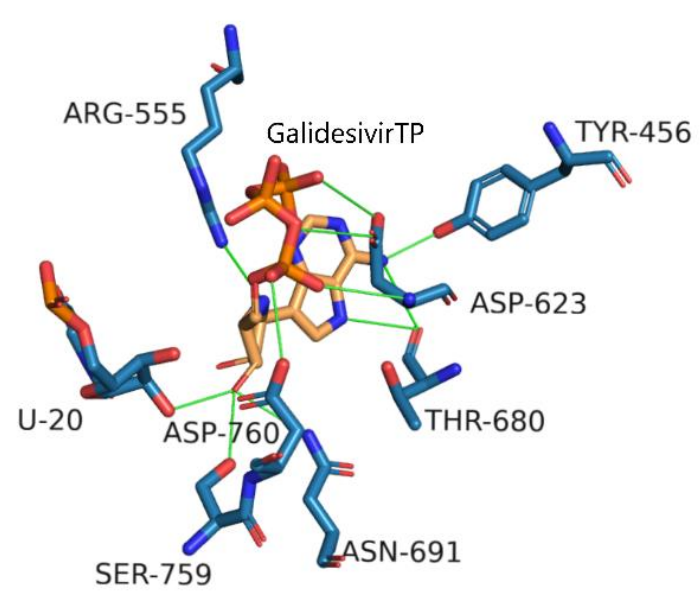

B

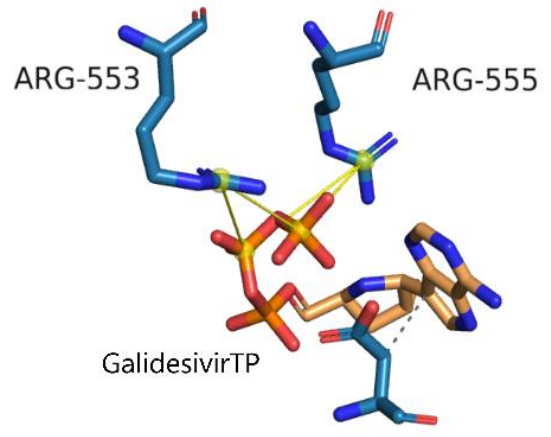

ASP-623

Figure 10. Galidesivir-TP ligand-protein interactions

Visualization of SARS-CoV-2 RdRp nsp12 active site and docked position with compound Galidesivir -TP model. Here, solid green lines depict the H-bonds, Solid Yellow lines depict salt-bridges while dashed grey lines depict hydrophobic interactions.

Taking in regards to the quick rate of mutations that COVID-19 does exhibit, that leads us to question what are the consequences of the possibility of COVID-19 developing a mutation in Arg555 amino acid? And how any mutation in this vital key residue (Arg555) would affect the efficiency of 
RdRp inhibitor (nucleotide analogs) drugs.

Based on results obtained from a cohort study of Remdesivir treated patients conducted by Alfredo Mari et al. no potential escape mutation was found in known key residue Nsp12:Arg555, as insilico structural models found that they were unlikely to be associated with loss of stability in RdRp [25]. These findings indicate that RdRp may represent a suitable drug target. A detailed understanding of the interaction of nucleotide analogs and RdRp especially at the atomic level using robust molecular technologies could lead to the development of highly specific and efficient new treatments for COVID19. Studies aiming to understand the structural and functional properties of key proteins involved in SARS-CoV-2 infection and replication and corresponding drug development activities should continue to be carried out to come out with more promising results.

\section{AUTHOR CONTRIBUTIONS}

Concept: S.G., Z.A.A.; Design: S.G., Z.A.A.; Control: S.G., Z.A.A.; Sources: S.G., Z.A.A.; Materials: S.G., Z.A.A.; Data Collection and/or processing: S.G., Z.A.A.; Analysis and/or interpretation: S.G., Z.A.A.; Literature review: S.G., Z.A.A.; Manuscript writing: S.G., Z.A.A.; Critical review: S.G., Z.A.A.; Other: -

\section{CONFLICT OF INTEREST}

The authors declare no conflict of interest.

\section{ETHICS COMMITTEE APPROVAL}

The authors declare that the ethics committee approval is not required for this study.

\section{REFERENCES}

1. Lai, C.C., Shih, T.P., Ko, W.C., Tang, H.J., Hsueh, P.R. (2020). Severe acute respiratory syndrome coronavirus 2 (SARS-CoV-2) and coronavirus disease-2019 (COVID-19): The epidemic and the challenges. International Journal of Antimicrobial Agents, 55(3), 105924. [CrossRef]

2. Qu, J., Cao, B., Chen, R. (2020). COVID-19 the essentials of prevention and treatment. Elsevier Science, p. 1-3

3. Pal, M., Berhanu, G., Desalegn, C., Kandi, V. (2020) Severe acute respiratory syndrome coronavirus-2 (SARS-CoV-2): An update. Cureus, 12(3), e7423. [CrossRef] 
4. Zhu, G., Zhu, C., Zhu, Y., Sun, F. (2020). Minireview of progress in the structural study of SARSCoV-2 proteins. Current Research in Microbial Sciences, 1, 53-61. [CrossRef]

5. Xia, X., Wang, Y., Zheng, J. C. (2021). Emerging roles of extracellular vesicles in mediating RNA virus infection. Fundamental Research, 1(2), 179-185. [CrossRef]

6. Lele, Z., Mansha, S., Dragoş S., Alvin, C., Jacqueline, G., Jeremy, D., Siobain, D., Julie, K.P. (2019). Existing host range mutations constrain further emergence of RNA viruses. Journal of Virology, 93(4), e01385-18. [CrossRef]

7. Ren, B. (2020). The AI-discovered aetiology of COVID-19 and rationale of the irinotecan+ etoposide combination therapy for critically ill COVID-19 patients. Medical Hypotheses, 144, 110385. [CrossRef]

8. Rasool, N., Yasmin, F., Sahai, S., Hussain, W., Inam, H., Arshad, A. (2021). Biological perspective of thiazolide derivatives against Mpro and MTase of SARS-CoV-2: Molecular docking, DFT and MD simulation investigations. Chemical Physics Letters, 771, 138463. [CrossRef]

9. Zhu, W., Chen, C., Gorshkov, K., Xu, M., Lo, D., Zheng, W. (2020). RNA-dependent RNA polymerase as a target for covid-19 drug discovery. Slas Discovery: Advancing The Science Of Drug Discovery, 25(10), 1141-1151. [CrossRef]

10. Demir-Tekol, S. (2020). SARS-CoV-2: Virolojisi ve tanıda kullanılan mikrobiyolojik testler. Southern Clinics of Istanbul Eurasia, 1(1), 8-12. [CrossRef]

11. Boopathi, S., Poma, A., Kolandaivel, P. (2020). Novel 2019 coronavirus structure, mechanism of action, antiviral drug promises and rule out against its treatment. Journal of Biomolecular Structure and Dynamics, 39(9), 3409-3418. [CrossRef]

12. Cheng, Y., Chao, T., Li, C., Chiu, M., Kao, H., Wang, S., Pang, Y., Lin, C., Tsai, Y., Lee, W., Tao, M., Ho, T., Wu, P., Jang, L., Chen, P., Chang, S., Yeh, S. (2020). Furin inhibitors block SARS-COV-2 spike protein cleavage to suppress virus production and cytopathic effects. Cell Reports, 33(2), 108254. [CrossRef]

13. Gao, Y., Yan, L., Huang, Y., Liu, F., Zhao, Y., Cao, L., Wang, T. (2020). Structure of the RNAdependent RNA polymerase from COVID-19 virus. Science, 368(6492), 779-782. [CrossRef]

14. Yin, W., Mao, C., Luan, X., Shen, D., Shen, Q., Su, H., Wang, X., Zhou, F., Zhao, W., Gao, M., Chang, S., Xie, Y., Tian, G., Jiang, H., Tao, S., Shen, J., Jiang, Y., Jiang, H., Xu, Y., Zhang, S., Zhang, Y., Xu, H. (2020). Structural basis for inhibition of the RNA-dependent RNA polymerase from SARS-CoV-2 by remdesivir. Science, 368(6498), 1499-1504. [CrossRef]

15. Kirchdoerfer, R.N., Ward, A.B (2019). Structure of the SARS-CoV nsp12 polymerase bound to nsp7 and nsp8 co-factors. Nature Communications, 10, 2342. [CrossRef]

16. Faheem Kumar, B., Sekhar, K., Kunjiappan, S., Jamalis, J., Balaña-Fouce, R., Tekwani, B., Sankaranarayanan, M. (2020). Druggable targets of SARS-CoV-2 and treatment opportunities for COVID-19. Bioorganic Chemistry, 104, 104269. [CrossRef]

17. Wang, M., Cao, R., Zhang, L., Yang, X., Liu, J., Xu, M., Shi, Z., Hu, Z., Zhong, W., Xiao, G. (2020). Remdesivir and chloroquine effectively inhibit the recently emerged novel coronavirus (2019-nCoV) in vitro. Cell Research, 30, 269-271. [CrossRef] 
18. Eastman, R., Roth, J., Brimacombe, K., Simeonov, A., Shen, M., Patnaik, S., Hall, M. (2020). Remdesivir: A review of its discovery and development leading to emergency use authorization for treatment of COVID-19. ACS Central Science, 6, 672-683. [CrossRef]

19. Bhatia, S., Narayanan, N., Nagpal, S., Nair, D.T. (2021). Antiviral therapeutics directed against RNA dependent RNA polymerases from positive-sense viruses. Molecular Aspects of Medicine, 10100. [CrossRef]

20. Tian, L., Qiang, T., Liang, C., Ren, X., Jia, M., Zhang, J., Li, J., Wan, M., YuWen, X., Li, H., Cao, W., Liu, H. (2021). RNA-dependent RNA polymerase (RdRp) inhibitors: The current landscape and repurposing for the COVID-19 pandemic. European Journal of Medicinal Chemistry, 213,113201. [CrossRef]

21. Sharma, P.L., Nurpeisov, V., Hernandez-Santiago, B., Beltran, T., Schinazi, R.F. (2004). Nucleoside inhibitors of human immunodeficiency virus type 1 reverse transcriptase. Current Topics in Medicinal Chemistry, 4, 895-919. [CrossRef]

22. Tiwari, V., Beer, J., Sankaranarayanan, N., Swanson-Mungerson, M., Desai, U. (2020). Discovering small-molecule therapeutics against SARS-CoV-2. Drug Discovery Today, 25(8), 1535-1544. [CrossRef]

23. Padhi, A., Shukla, R., Saudagar, P., Tripathi, T. (2021). High-throughput rational design of the Remdesivir binding site in the RdRp of SARS-CoV-2: implications for potential resistance. iScience, 24(1), 101992. [CrossRef]

24. Gordon, C., Tchesnokov, E., Woolner, E., Feng, J., Porter, D., Götte, M. (2020). Remdesivir is a direct-acting antiviral that inhibits RNA-dependent RNA polymerase from severe acute respiratory syndrome coronavirus 2 with high potency. Journal of Biological Chemistry, 295(20), 6785-6797. [CrossRef]

25. Mari, A., Roloff, T., Stange, M., Søgaard, K.K., Asllanaj, E., Tauriello, G., Alexander, L.T., Schweitzer, M., Leuzinger, K., Gensch, A., Martinez, A.E., Bielicki, J., Pargger, H., Siegemund, M., Nickel, C.H., Bingisser, R., Osthoff, M., Bassetti, S., Sendi, P., Battegay, M., Marzolini, C., Seth-Smith, H.M.B., Schwede, T., Hirsch, H.H., Egli, A. (2021). Global genomic analysis of SARS-CoV-2 RNA dependent RNA polymerase evolution and antiviral drug resistance. Microorganisms 19, 9(5), 1094. [CrossRef] 